\title{
Behaviour and repair of carpentry connections - Rotational behaviour of the rafter and tie beam connection in timber roof structures
}

\author{
Pedro Palma ${ }^{\mathrm{a}, *}$, Helena Garcia ${ }^{\mathrm{b}}$, João Ferreira ${ }^{\mathrm{c}}$, João Appleton ${ }^{\mathrm{d}}$, Helena Cruz ${ }^{\mathrm{a}}$ \\ a National Laboratory for Civil Engineering, Timber Structures Division, Avenue Brasil 101, 1700-066 Lisboa, Portugal \\ ${ }^{\mathrm{b}}$ Tecnovia-Sociedade de Empreitadas S.A., Casal do Deserto, 2740-135 Porto Salvo, Portugal \\ c Technical University of Lisbon, Department of Civil Engineering and Architecture (ICIST/IST/UTL), Avenue Rovisco Pais, $1049-001$ Lisboa, Portugal \\ d A2P Consult Estudos e Projectos, Lda, Rua Acácio de Paiva, 27, 2॰ , 1700-004 Lisboa, Portugal
}

\section{A R T I C L E I N F O}

\section{Article history:}

Received 12 January 2012

Accepted 13 March 2012

Available online xxx

\section{Keywords:}

Timber structures

Connections

Carpentry connections

Tests

Repair

Reinforcement

\begin{abstract}
A B S T R A C T
An extensive experimental campaign on structural carpentry connections, namely the rafter and tie beam connection, was conducted to assess their rotational behaviour and the effectiveness of some common repair and reinforcement techniques. The mechanical behaviour was appraised for different geometries, metal fastening devices and moisture content of timber. After the mechanical tests, some of the connections were repaired and tested again, which allowed comparing the performance of the original and the repaired connections. The compressive internal force in the rafter influences the connection's behaviour, being crucial in maintaining the integrity of some of these carpentry joints. This aspect required a complex test apparatus and the design of specific equipment to simultaneously apply the compression force and the rotations in the rafter specimen. The experimental results show that some configurations exhibit enough rotation stiffness and load bearing capacity to be accounted for when appraising the roof structures they belong to, enhancing the common assumption of hinged joints. The connection's behaviour is different when opening or closing the skew angle. Each connection typology exhibits specific load bearing mechanisms which dictate different performances and failure modes, which should be considered when devising a repair.
\end{abstract}

(c) 2012 Elsevier Masson SAS. All rights reserved.

\section{Research aims}

The research presented in this paper aims at characterizing the mechanical behaviour of structural carpentry connections in timber roof trusses and appraise the effectiveness of some common repair and reinforcement techniques. The results are intended to provide guidance to the engineers involved in the structural assessment of existing timber structures and planning the repair or reinforcement interventions, regarding the performance of the carpentry connections, which play a major role in the overall structural behaviour.

\section{Introduction}

Connections in old timber structures, namely in roof structures, usually rely on notches on the structural elements, through which the internal forces are transmitted by compression and

\footnotetext{
* Corresponding author. Tel.: +35121 8443893.

E-mail addresses: ppalma@Inec.pt (P. Palma), helena.garcia@tecnovia.pt (H. Garcia), joao.ferreira@civil.ist.utl.pt (J. Ferreira), joao.appleton@a2p.pt (J. Appleton), helenacruz@lnec.pt (H. Cruz).
}

friction in the contact surfaces. These connections are often complemented with metal parts, some added during construction, e.g. to allow the connections to withstand tensile forces, or to increase their strength or stiffness, and some are added later, to repair or strengthen underperforming connections.

As current design standards [1] and building codes focus primarily on modern industrialized mechanical or bonded timber connections, they provide little or no guidance to engineers involved in the assessment of existing structures, who often face difficulties when making assumptions about the behaviour of carpentry connections. In addition, current guidelines and standards point towards maintaining the connections' "original stiffness" [2,3], reserving stiffening intervention techniques to extreme degradation scenarios, because of their influence in the overall structural behaviour. Likewise, the growing interest in carpentry connections has increased the demand for design methods, in part due to the development of CAD/CAM systems and CNC machinery which makes it possible and affordable to produce complex and accurate timber members and connections.

Therefore, it is necessary to establish design and detailing rules and to provide criteria for the assessment of carpentry connections in existing structures, as well as recommendations for repair or strengthening interventions. 